\title{
A Novel Simple Dipping-Nebulizing Water Absorption for Biogas Purification
}

\author{
Totok Soehartanto ${ }^{1 *}$, Ruri Agung Wahyuono ${ }^{2}$, Putri Yeni Aisyah ${ }^{1}$, Biondhi Ubaidillah ${ }^{1}$ \\ ${ }_{1}^{1}$ Department of Instrumentation, Faculty of Vocation, Institut Teknologi Sepuluh Nopember (ITS), Jl. Arief \\ Rahman Hakim, ITS campus Keputih, Sukolilo, 60111 Surabaya, Indonesia \\ ${ }^{2}$ Department of Engineering Physics, Faculty of Industrial Technology and System Engineering, Institut \\ Teknologi Sepuluh Nopember (ITS), Jl. Arief Rahman Hakim, ITS campus Keputih, Sukolilo, 60111 \\ Surabaya, Indonesia
}

\begin{abstract}
Biogas impurities $\mathrm{CO}_{2}$ and $\mathrm{H}_{2} \mathrm{~S}$ decrease the quality of biogas, which leads to a reduced caloric value and corrosive behavior, respectively. A vertical/columnar wet scrubber has been widely employed for biogas purification in which the absorption of impurities strongly depends on the contact time and surface area between the biogas and water. The drawback of this method lies in the stability of $\mathrm{CH}_{4}$ production due to the influence of the bioreactor conditions and the fluctuating condition of the surrounding environment. In this work, we present a novel design of simple water absorption columns embedded with an ultrasonic nebulizer for biogas purification. In this designed system, $\mathrm{CO}_{2}$ and $\mathrm{H}_{2} \mathrm{~S}$ become dissolved in the water, as the $\mathrm{CH}_{4}$ characterized by water low solubility is released on the surface of the water by using an ultrasonic diffuser/nebulizer. We optimized the water absorption performance by varying the water $\mathrm{pH}$ in the range 6.0-7.3. The results indicate that water $\mathrm{pH}$ affects biogas purification in the designed system. The optimum $\mathrm{pH}$ condition was 6.78, which yielded $\mathrm{CH}_{4}$ enrichment of $11 \%, \mathrm{O}_{2}$ increase of $29 \%, \mathrm{CO}_{2}$ reduction of $32 \%$, and $\mathrm{H}_{2} \mathrm{~S}$ reduction of $99.8 \%$. To evaluate the biogas purification process in the upscaled system, a model and SIMULINK-based simulation were developed to predict the biogas purification process.
\end{abstract}

Keywords: $\mathrm{CH}_{4}$ enrichment; Impurities removal; Modeling and simulation; Water $\mathrm{pH}$

\section{Introduction}

Biogas is a renewable energy source generated from anaerobic processes of organic substrates, such as animal, plant, or household organic waste (Petersson, 2014; Ghatak and Mahanta, 2017). Typically, biogas contains methane $\left(\mathrm{CH}_{4}\right)$, carbon dioxide $\left(\mathrm{CO}_{2}\right)$, and hydrogen sulfide $\left(\mathrm{H}_{2} \mathrm{~S}\right)$ (Arutyunov et al., 2020). $\mathrm{CH}_{4}$ can be used as an energy source for electricity generation, vehicle fuel, or as a raw material in the industry ( Wahyuono et al., 2015; Chen et al., 2017). However, the other gases contained in biogas are considered impurities. For example, $\mathrm{CO}_{2}$ which causes ozone depletion and lowers the heating value of biogas, and $\mathrm{H}_{2} \mathrm{~S}$ is so strongly corrosive and can damage industrial equipment that uses biogas. Therefore, the recent development of biogas technology not only focuses on biogas production but also on the biogas purification process, particularly the removal of $\mathrm{CO}_{2}$ and $\mathrm{H}_{2} \mathrm{~S}$ (Baena-Moreno et al., 2019).

There exist various biogas purification methods including physical and chemical absorption, adsorption, gas permeation through the membrane, and cryogenic methods 
(Horikawa et al., 2004; Abatzoglou and Boivin, 2009; Ofori-Boateng and Kwafie, 2009; Songolzadeh et al., 2014; Belaissaoui et al., 2016; Kusrini et al., 2016; Maile et al., 2017;). Of these, the spray-type wet scrubber is widely utilized in the industry for biogas purification, as the process is relatively simple with strong adaptability. The spraying water scrubber passes the biogas in the vertical vessel, and the water is sprayed from the top of the vessel (Wang et al., 2020). In the spray-type wet scrubber method, the effectiveness of impurities absorption is controlled by the dimension of the wet scrubber, as the absorption is a function of the contact surface area and contact duration (Tahir et al., 2015; Sarono et al., 2016; Kapoor et al., 2017; Noorain et al., 2019). This in turn leads to the high cost of construction and operation of the spray-type wet scrubber. Moreover, the spray-type wet scrubber is known to be merely effective for absorbing $\mathrm{CO}_{2}, \mathrm{H}_{2} \mathrm{~S}$ or other impurities in biogas but unable to stabilize or maintain the $\mathrm{CH}_{4}$ concentration in biogas (Islamiyah et al., 2015). Therefore, $\mathrm{CH}_{4}$ gas accumulation process will not occur in the spray-type wet scrubber method as the purified biogas will pass directly through the biogas outlet to be used as an energy source (Wang et al., 2020). It should also be noted that $\mathrm{CH}_{4}$ concentration in biogas varies as the operational condition of the anaerobic bioreactor is altered. Practically, $\mathrm{CH}_{4}$ concentration must be kept to a minimum value $(\sim 65 \%)$ so that the energy source is sufficient to meet the minimum load (Shah et al., 2016).

In this work, we propose a new system of purification that dissolves biogas into a water absorption system that consists of two absorption columns, the so-called dippingnebulizing water absorption system. This proposed system addresses the abovementioned drawbacks of vertical spray type water scrubber. The purification process in the proposed system mainly combines a dissolution technique by dipping the biogas outlet into water and a nebulizing technique to pull off the dissolved $\mathrm{CH}_{4}$ to the water surface, with its subsequent release in the head space of the main water absorption column. The proposed dipping-nebulizing water absorption system has been proven to work with relatively high purification efficiency. Furthermore, this proposed system does not require many mechanical components; hence, the operational cost of the upscaled system should not be a major concern. Additionally, a SIMULINK simulation based on the mathematical model for biogas purification was performed to offer insights into the proposed process in an upscaled dimension.

\section{Methods}

\subsection{The Dipping-Nebulizing Water Absorption Columns}

The prototype of the biogas purification system developed in this work was constructed by assembling two water absorption columns equipped with an ultrasonic pump (Figure 1). The dimension of the water absorption column was calculated based on the volume of water used as a medium for absorbing impurities in biogas. The volume of water was determined considering the flow rate of biogas entering the first column, which follows the law of molecular diffusion below:

$$
\frac{\partial m}{\partial t}=-D \frac{\partial c}{\partial x}
$$

where $m$ is the mass of biogas $(\mathrm{kg}), D$ is the diffusion coefficient of biogas in certain medium $\left(\mathrm{m}^{2 \cdot} \mathrm{s}^{-1}\right)$, and $c$ is the concentration of biogas $(\mathrm{M})$. 

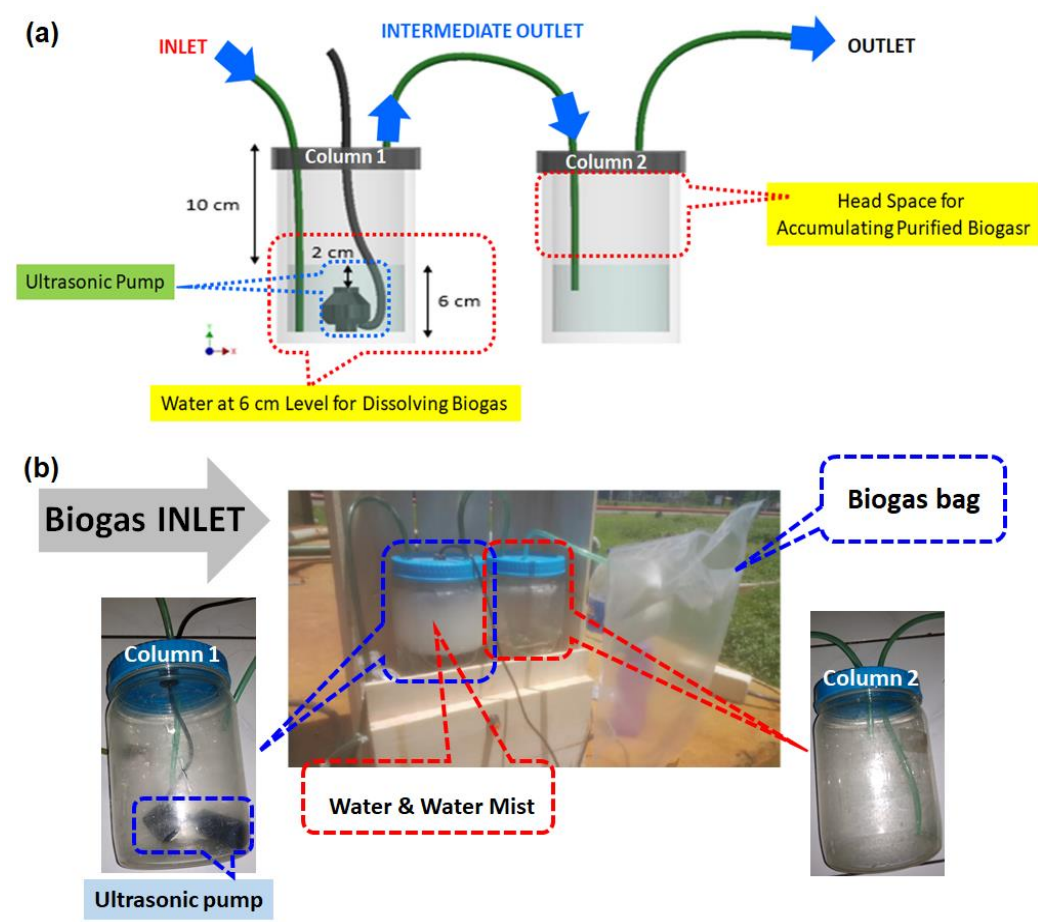

Figure 1 (a) Design of the novel dipping-nebulizing water absorption columns for the biogas purification; and (b) the resultant prototype for the biogas purification test

The working principle of the proposed water absorption-based purification system could be described as follows: The biogas is streamed through the first water absorption column in which the hose ends inside the water and, hence, all gases should be dissolved in water. Depending on the solubility, the gas will either be dissolved and react with water molecules (particularly for $\mathrm{CO}_{2}$ and $\mathrm{H}_{2} \mathrm{~S}$ ) or diffuse toward the water surface and be released to the head space of the first water absorption column. Of note is the ultrasonic diffuser pump employed and placed at the bottom of the first water column to nebulize the $\mathrm{CH}_{4}$ as well as create a water mist within the head space. This mixture of $\mathrm{CH}_{4}$ and vaporized water molecules is barely soluble in water. The accumulated $\mathrm{CH}_{4}$ and $\mathrm{H}_{2} \mathrm{O}$ molecules in the head space of the first water absorption column are then transferred to the second water absorption column through a hose with an end dipped into the second water absorption column. The released $\mathrm{CH}_{4}$ from the second water column is considered an output of the system-the purified biogas.

\subsection{Biogas Purification Test}

To test the biogas purification, an experiment was carried out directly at the bioethanol plant in East Java, where an anaerobic bioreactor was installed. The experiment was intentionally done in the rainy season when the physicochemical condition of the anaerobic bioreactor was less stable due to the fluctuating ambient condition, and hence the biogas quality $\left(\mathrm{CH}_{4}\right.$ concentration) was relatively low. Assessment of the designed dippingnebulizing water absorption system was undertaken by characterizing the gas content in biogas before and after purification in the batch experiments for 10 days. The analysis of biogas composition resulted in four main gas constituents: $\mathrm{CH}_{4}, \mathrm{O}_{2}, \mathrm{CO}_{2}$, and $\mathrm{H}_{2} \mathrm{~S}$. The water source for dissolving the biogas was varied in this purification test to obtain the optimum water condition to purify the biogas from impurities. In particular, various water $\mathrm{pH}$ levels were exploited using the commercially available water of $\mathrm{pH} 6.06,6.78$, and 6.90 and the well water ( $\mathrm{pH} 7.28$ ) in the experimental site. 


\subsection{Modeling and Simulation of Biogas Purification in Upscaled Systems}

To evaluate the proposed biogas purification system upon upscaling, the process was modeled and solved. As indicated earlier, biogas contains several types of gas constituents (see Table 1) at different concentrations (moles, $n$ ). Each mole of the gas constituent contributes a partial pressure, which is proportional to the percentage of the gas, as stated in Charles Boyle's Law below:

$$
P V=\beta T
$$

where $P$ is the partial pressure of gas $(\mathrm{Pa}), V$ is the volume of gas $(\mathrm{L}), \beta$ is a constant, and $T$ is the temperature of gas $(\mathrm{K})$.

Table 1 Biogas content (Recebli et al., 2015)

\begin{tabular}{lc}
\hline \multicolumn{1}{c}{ Type of gas } & $\begin{array}{c}\text { Total volumetric } \\
\text { concentration }(\%)\end{array}$ \\
\hline Methane $\left(\mathrm{CH}_{4}\right)$ & 65.7 \\
Carbon dioxide $\left(\mathrm{CO}_{2}\right)$ & 27 \\
Nitrogen $\left(\mathrm{N}_{2}\right)$ & 2.3 \\
Oxygen $\left(\mathrm{O}_{2}\right)$ & 1 \\
Propane $\left(\mathrm{C}_{3} \mathrm{H}_{8}\right)$ & 0.7 \\
Hydrogen Sulfide $\left(\mathrm{H}_{2} \mathrm{~S}\right)$ & Not measurable \\
\hline
\end{tabular}

Table 2 The effect of impurities gas on biogas (Abdurrakhman et al., 2018)

\begin{tabular}{ccl}
\hline Component & Total (\%) & Effect \\
\hline $\mathrm{CO}_{2}$ & $25-50$ & $\begin{array}{l}\text { Reduces the combustion heat value } \\
\text { Causes corrosion if the gas is sufficiently wet } \\
\text { Increases knocking on the engine }\end{array}$ \\
$\mathrm{H}_{2} \mathrm{~S}$ & $0-0.5$ & $\begin{array}{l}\text { Causes corrosion in equipment and piping systems } \\
\text { Causes } \mathrm{SO}_{2} \text { emissions } \\
\text { Damages the catalyst }\end{array}$ \\
\hline
\end{tabular}

It should also be noted that not all constituents are useful in terms of energy. As listed in Table 1, the gas constituents that are mostly found in biogas are $\mathrm{CH}_{4}, \mathrm{CO}_{2}$, and $\mathrm{H}_{2} \mathrm{~S}$. $\mathrm{CH}_{4}$ is used as an energy source, whereas $\mathrm{CO}_{2}$ and $\mathrm{H}_{2} \mathrm{~S}$ are impurities in biogas (Macgregor and Mather, 1991). Evaluating the process in the upscaled system requires a proper physical/mathematical model that represent the whole process. The dissolution process was modelled using the law of gas balance: the impurities in biogas have a partial gas pressure that is proportional to its composition so that gas with a certain temperature and volume will have a certain pressure following the Dalton's law. The partial pressure of gas allows the gas to dissolve into the water medium following Henry's Law (kinematics of transfer of gas into water) (Fu et al., 1996). The impurities in biogas in this work were limited to $\mathrm{CO}_{2}$ and $\mathrm{H}_{2} \mathrm{~S}$. The proposed method of dissolving biogas in water was expected to be more effective in absorbing the impurities as compared to the spray-type wet scrubber method that requires a pump to drain and spray water from the top of the vertical vessel. 

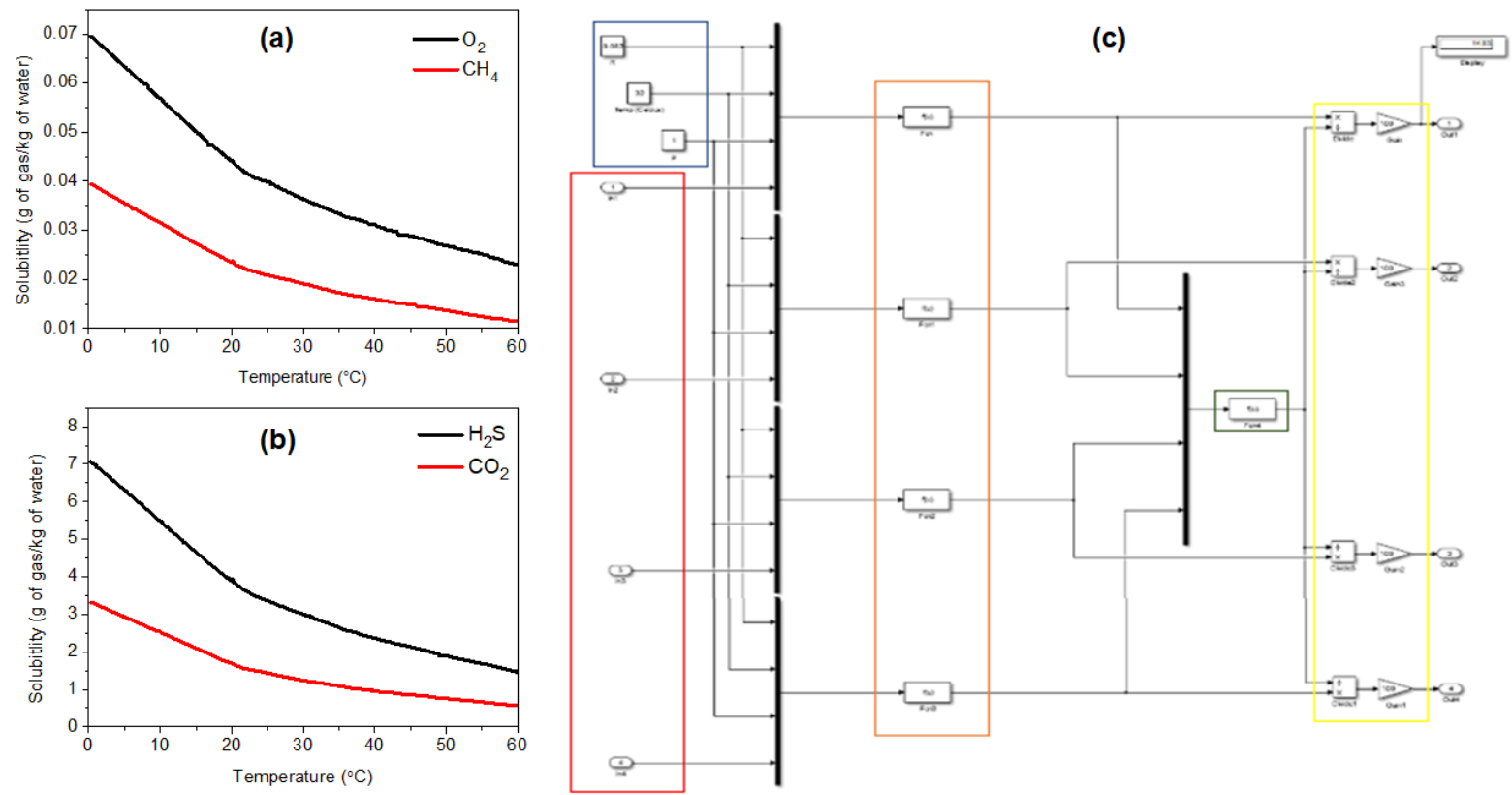

Figure $2(a, b)$ The solubility profile of each biogas constituent in water and (c) a model developed using SIMULINK representing the biogas purification using water absorption. The blue part is the constant input, including $\mathrm{R}$ (gas constant), $\mathrm{P}$ (pressure), and $\mathrm{T}$ (temperature). The sub-system within the red block is the input of the subsystem (2), $\mathrm{m}_{\text {outlet }}$ of biogas. The sub-system within the orange block is the conversion of $m_{\text {outlet }}$ to volume. The sub-system within the green block is the summation of gas constituents, $\mathrm{CO}_{2}, \mathrm{H}_{2} \mathrm{~S}, \mathrm{CH}_{4}$, and $\mathrm{O}_{2}$. The sub-system within the yellow block calculates the percentage of each gas constituent after purification.

Considering the different solubility of gas constituents in biogas (Figure 2a and Figure $2 \mathrm{~b}$ ), the system was modeled using SIMULINK, as depicted in Figure 2c. The solubility of $\mathrm{CO}_{2}$ in water served as a buffer system of carbon dioxide bicarbonate $\left(\mathrm{H}_{2} \mathrm{CO}_{3}\right)$ found in most waters in nature. $\mathrm{CO}_{2}$ could diffuse into the water through the absorption system, where the solubility of $\mathrm{CO}_{2}$ in water could be described as follows (Macgregor and Mather, 1991):

$$
\mathrm{CO}_{2}+\mathrm{H}_{2} \mathrm{O} \stackrel{k}{\leftrightarrow} \mathrm{H}_{3} \mathrm{O}^{+}+\mathrm{HCO}_{3}^{-}
$$

The solubility of $\mathrm{H}_{2} \mathrm{~S}$ in water based on the equilibrium reaction has been found to depend on the $\mathrm{pH}$ of the medium. Lower solution $\mathrm{pH}$ shifts the equilibrium toward the formation of $\mathrm{H}_{2} \mathrm{~S}$ and consequently decreases the solubility of $\mathrm{H}_{2} \mathrm{~S}$ in the solution (Macgregor and Mather, 1991):

$$
\mathrm{H}_{2} \mathrm{~S}+\mathrm{H}_{2} \mathrm{O} \stackrel{k}{\leftrightarrow} \mathrm{H}_{3} \mathrm{O}^{+}+H S^{-}
$$

\section{Results and Discussion}

The biogas purification results using various water sources in the proposed dippingnebulizing water absorption system are summarized in Figure 3 and Figure 4. In general, the $\mathrm{pH}$ of water plays a role in determining purification efficiency. The output of gas constituents with low solubility in water, including $\mathrm{CH}_{4}$ and $\mathrm{O}_{2}$, is also affected by $\mathrm{pH}$. Thus, increasing $\mathrm{pH}$ results in an increase in the solubility of $\mathrm{CH}_{4}$ and $\mathrm{O}_{2}$ (Latif et al., 2014; Gross and Cravotta III, 2016). In this observation, at a higher $\mathrm{pH}$ (7.28), the concentration of $\mathrm{CH}_{4}$ and $\mathrm{O}_{2}$ in purified biogas was lower than that of the initial state of the biogas. This indicates that at higher $\mathrm{pH}$, the solubility of other constituents, such as $\mathrm{CO}_{2}$ and $\mathrm{H}_{2} \mathrm{~S}$ also increases. 
Hence, the concentration of $\mathrm{CH}_{4}$ and $\mathrm{O}_{2}$ in the outlet of the system was balanced by the concentration of $\mathrm{CO}_{2}$ and $\mathrm{H}_{2} \mathrm{~S}$ that escaped from the dipping water. Furthermore, with the well water of $\mathrm{pH} 7.28$, the $\mathrm{O}_{2}$ concentration was close to the concentration of $\mathrm{CO}_{2}$ due to the metabolism of other living organisms in the solvent medium (Revsbech et al., 2019).
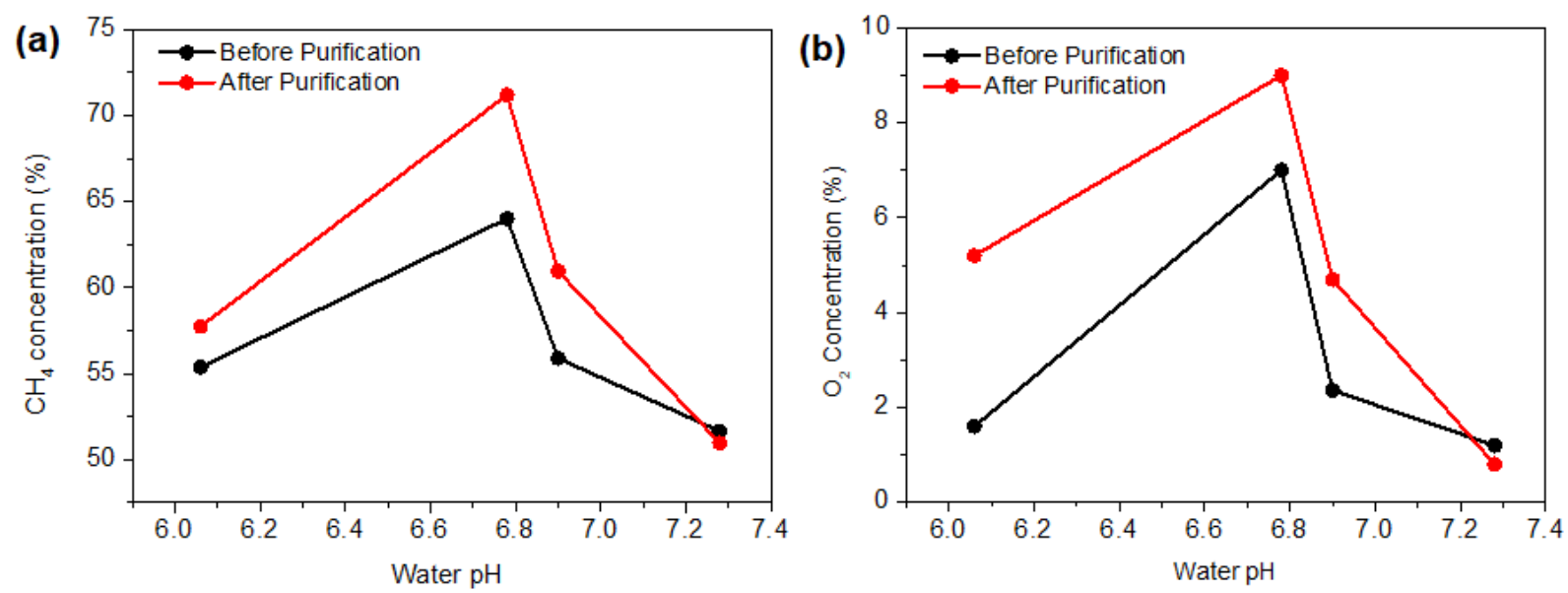

Figure 3 (a) $\mathrm{CH}_{4}$ and (b) $\mathrm{O}_{2}$ concentration before and after purification using the dipping-nebulizing water absorption system at different water $\mathrm{pH}$ levels
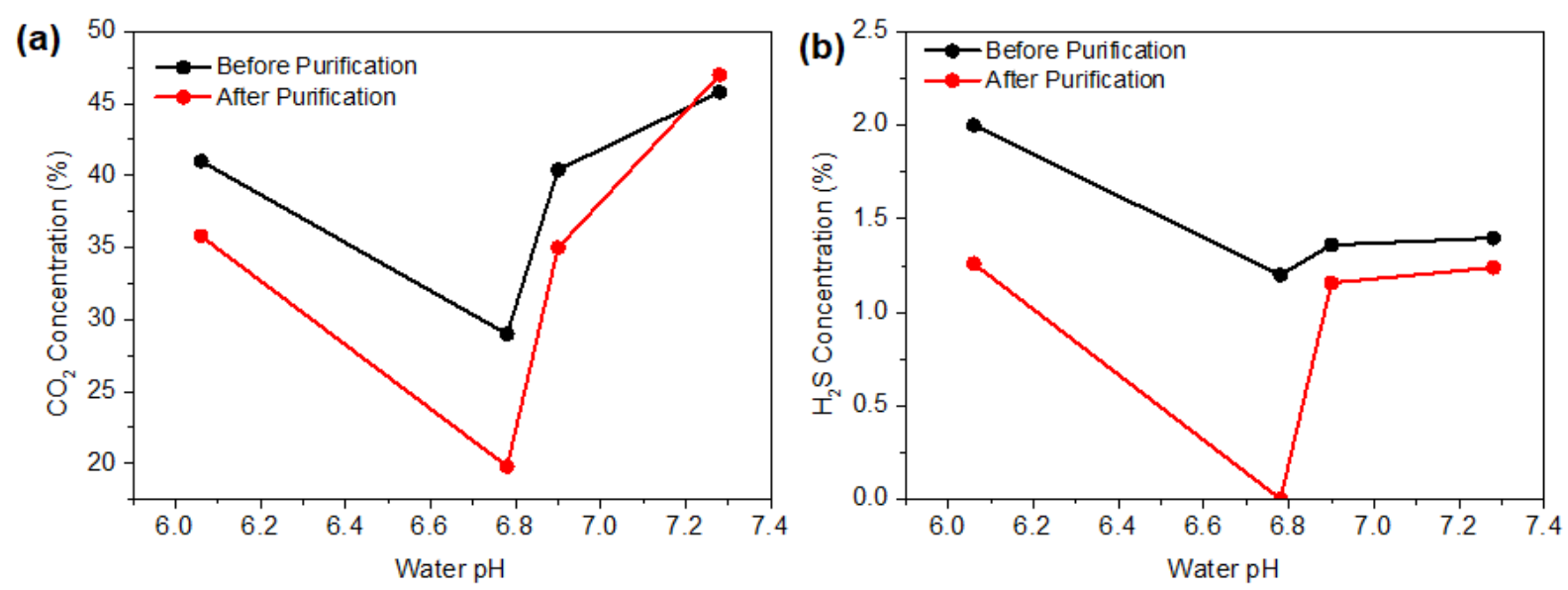

Figure 4 (a) $\mathrm{CO}_{2}$ and (b) $\mathrm{H}_{2} \mathrm{~S}$ concentration before and after purification using the dippingnebulizing water absorption system at different water $\mathrm{pH}$ levels

Figure 4 depicts the concentration of outlet $\mathrm{CO}_{2}$ and $\mathrm{H}_{2} \mathrm{~S}$ upon biogas purification. As the solubilities of $\mathrm{CO}_{2}$ and $\mathrm{H}_{2} \mathrm{~S}$ became much higher than those of $\mathrm{CH}_{4}$ and $\mathrm{O}_{2}$ (see Figure $2 \mathrm{a}$ and Figure $2 \mathrm{~b}$ ), the absorption of these gas impurities in water became more efficient. It is known that increasing the $\mathrm{pH}$ of the solvent medium also increases the solubility of both $\mathrm{CO}_{2}$ and $\mathrm{H}_{2} \mathrm{~S}$ (Lin, 2004). Therefore, it is plausible that the trend of $\mathrm{CO}_{2}$ and $\mathrm{H}_{2} \mathrm{~S}$ concentration is the inverse of the trend of $\mathrm{CH}_{4}$ and $\mathrm{O}_{2}$ with increasing water $\mathrm{pH}$. Overall, it should be noted that the $\mathrm{CH}_{4}$ content upon purification remained the same. However, the volume fraction of $\mathrm{CH}_{4}$ increased as the fraction of $\mathrm{CO}_{2}$ and $\mathrm{H}_{2} \mathrm{~S}$ is partially absorbed by the water. 


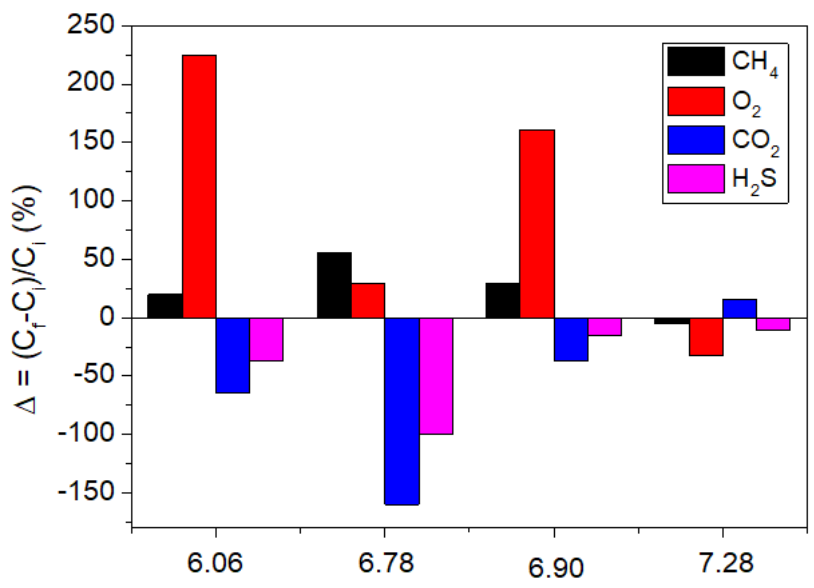

Figure 5 Concentration change $\left(\mathrm{C}_{\mathrm{f}}-\mathrm{C}_{\mathrm{i}}\right)$ of each biogas component, including $\mathrm{CH}_{4}, \mathrm{O}_{2}, \mathrm{CO}_{2}$, and $\mathrm{H}_{2} \mathrm{~S}$, relative to the initial concentration $\left(\mathrm{C}_{\mathrm{i}}\right)$ concentration before purification using the dippingnebulizing water absorption system at different water $\mathrm{pH}$ levels. $\mathrm{CH}_{4}$ and $\mathrm{CO}_{2}$ value are $5 \times$-amplified for visibility in the figure.
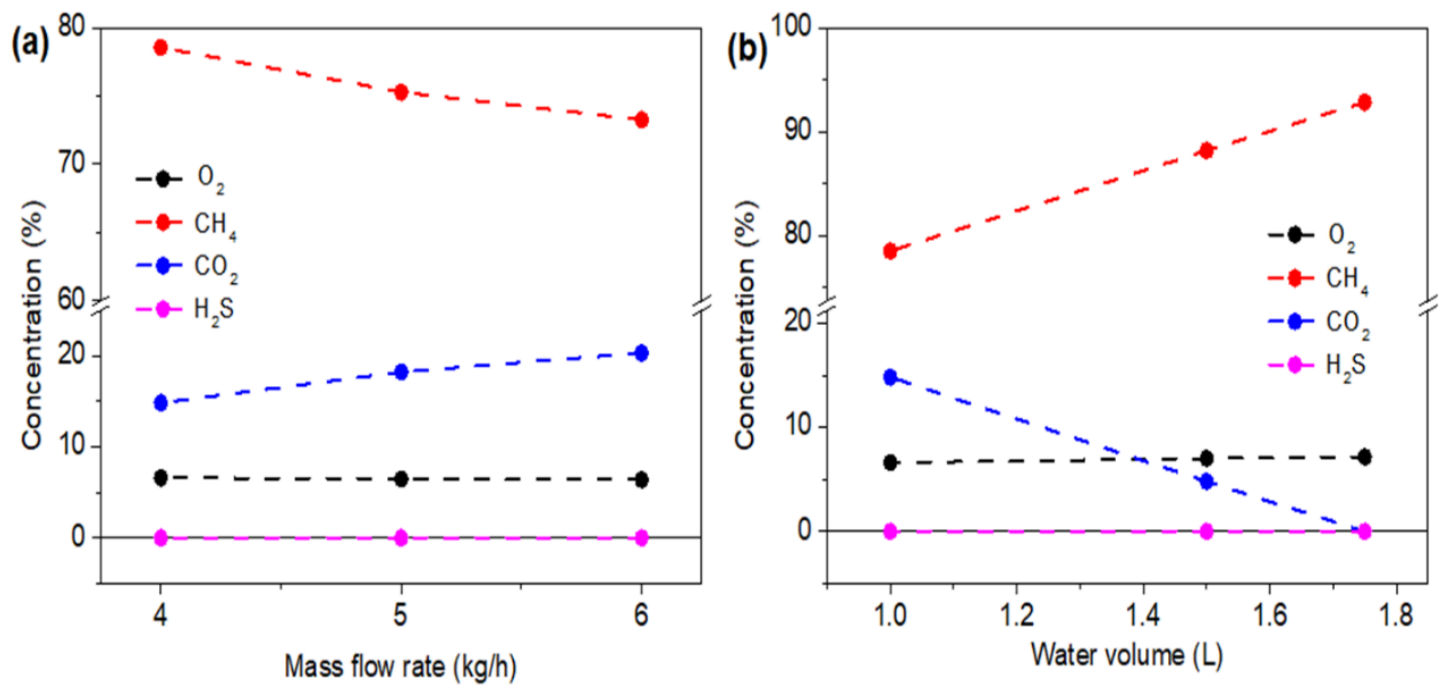

Figure 6 Simulation results of biogas purification with varying (a) mass flow rate $\left(\mathrm{T}=32^{\circ} \mathrm{C}\right.$, volume $=1 \mathrm{~L})$ and $(\mathrm{b})$ volume of water $\left(\mathrm{T}=32^{\circ} \mathrm{C}\right.$, mass flow rate $\left.=4 \mathrm{~kg} \cdot \mathrm{h}^{-1}\right)$. The volumetric concentration of gas constituents at the inlet is kept constant: $\mathrm{CO}_{2}(29 \%), \mathrm{H}_{2} \mathrm{~S}(1 \%), \mathrm{O}_{2}(6 \%)$, and $\mathrm{CH}_{4}(64 \%)$.

To extract meaningful information from the biogas purification test, a bar chart of $\Delta$ vs $\mathrm{pH}$ is presented in Figure 5. $\Delta$ is a \% change of concentration of each gas constituent relative to its corresponding initial concentration. At optimum purification conditions, highly positive $\Delta$ amplitude is expected for $\mathrm{CH}_{4}$, whereas a highly negative $\Delta$ amplitude is favorable for $\mathrm{CO}_{2}$ and $\mathrm{H}_{2} \mathrm{~S}$. It is clear from the data presented below that the highest positive $\Delta$ for $\mathrm{CH}_{4}$ enrichment was obtained at $\mathrm{pH}$ 6.78. Water solvent at $\mathrm{pH} 6.78$ enabled purification of biogas to reach a minimum percentage of $\mathrm{CH}_{4}$ concentration (> 65\%), which is required to efficiently drive the load. This result is in agreement with the literature (Latif et al., 2014) that reports that $\mathrm{CH}_{4}$ production is maximum using a medium at $\mathrm{pH}$ 6.85. Consistently, the highest negative $\Delta$ for $\mathrm{CO}_{2}$ and $\mathrm{H}_{2} \mathrm{~S}$ reduction was observed for biogas purification using water with $\mathrm{pH} 6.78$. Thus, it can be deduced that the optimum operating condition of the novel dippingnebulizing water absorption system can be achieved by using a water source with $\mathrm{pH}$ of $\sim 6.8$. Nonetheless, it is worth noting that the increment of $\mathrm{pH}$ investigated in this study is 
too sparse in the range 6.0-6.9. Therefore, future optimization by titrating the water medium such that a finer $\mathrm{pH}$ increment is employed will be evaluated to assess the potential for a more precise optimized $\mathrm{pH}$.

Having assessed the performance of our proposed system, biogas purification in an upscaled dipping-nebulizing water absorption system was evaluated using a model created using SIMULINK. The performance of the biogas purification system under varying conditions of mass flow rates and water volumes is shown in Figure 6. The biogas input was set identical with the following composition: $\mathrm{CH}_{4}(64 \%), \mathrm{O}_{2}(6 \%), \mathrm{CO}_{2}(29 \%)$, and $\mathrm{H}_{2} \mathrm{~S}(1 \%)$. Figure 6 a depicts the biogas contents after purification with increasing mass flow rate. We found that increasing the mass flow rate from 4 to $6 \mathrm{~kg} / \mathrm{h}$ had a tendency to prominently increase $\mathrm{CO}_{2}$ concentration, with only a minor decrease in $\mathrm{CH}_{4}$ concentration. Therefore, further assessment of the modeled system was based on the $4 \mathrm{~kg} / \mathrm{h}$ mass flow rate. Increasing the volume of water from 1 to $1.75 \mathrm{~L}$ yielded an increasing $\mathrm{CH}_{4}$ concentration and significantly suppressed $\mathrm{CO}_{2}$ content. Hence, the best result under the defined operating condition can be achieved when the upscaled system operates at $4 \mathrm{~kg} / \mathrm{h}$ mass flow rate and the volume is set at $1.75 \mathrm{~L}$.

\section{Conclusions}

A miniaturized dipping-nebulizing water absorption system for biogas purification has been successfully developed, especially for $\mathrm{CO}_{2}$ and $\mathrm{H}_{2} \mathrm{~S}$ reduction. The ultrasonic nebulizer was embedded in one of the bioreactor's water absorption columns to extract $\mathrm{CH}_{4}$ out from the first water volume for purification. The biogas purification was found to be water-pH dependent, and an optimum $\mathrm{pH}$ condition was observed. Of the investigated $\mathrm{pH}$ levels, the highest purification of biogas was achieved by using water with a $\mathrm{pH}$ of 6.78 . At the optimum $\mathrm{pH}$ condition, the concentration of $\mathrm{CH}_{4}$ and $\mathrm{O}_{2}$ increased by 11 and 29\%, respectively, whereas $\mathrm{CO}_{2}$ and $\mathrm{H}_{2} \mathrm{~S}$ was efficiently suppressed by as much as 32 and $99.8 \%$, respectively. To upscale the system, better operational conditions were simulated using a model. Further research will focus on the optimization of water $\mathrm{pH}$ to yield higher $\mathrm{CH}_{4}$.

\section{Acknowledgements}

The author would like to thank Badan Riset dan Inovasi Nasional Republik Indonesia for providing research assistance through the Hibah Rencana Induk Riset Nasional scheme (Grant Contract Number : 132/5P2H/LT/DRPM/2018).

\section{References}

Abatzoglou, N., Boivin, S., 2009. A Review of Biogas Purification Processes. Biofuels, Bioproducts \& Biorefining, Volume 3, pp. 42-71

Abdurrakhman, A., Adhim, M.M., Widjiantoro, B.L., 2018. Optimization of $\mathrm{H}_{2} \mathrm{~S}$ Absorption toward the Alteration in Flow Rate of Biogas Purification System with Water Scrubber using Particle Swarm Optimization. In: AIP Conference Proceedings, Volume 1983, 020014

Arutyunov, V., Nikitin, A., Strekova, L., Savchenko, V., Sedov, I., 2020. Utilization of Renewable Sources of Biogas for Small-Scale Production of Liquid Fuels. Catalysis Today, In Press, Corrected Proof. doi.org/10.1016/j.cattod.2020.06.057

Baena-Moreno, F.M., Rodríguez-Galán, M., Vega, F., Vilches, L.F., Navarrete, B., 2019. Review: Recent Advances in Biogas Purifying Technologies. International Journal of Green Energy, Volume 16(5), pp. 401-412 
Belaissaoui, B., Claveria-Baro, J., Lorenzo-Hernando, A., Zaidiza, D.A., Chabanon, E., Castel, C., Rode, S., Roizard, D., Favre, E., 2016. Potentialities of a Dense Skin Hollow Fiber Membrane Contactor for Biogas Purification by Pressurized Water Absorption. Journal of Membrane Science, Volume 513, pp. 236-249

Chen, Y., Moloney, J.G., Christensen, K.E., Moloney, M.G., 2017. Fused-ring Oxazolopyrrolopyridopyrimidine Systems with Gram-Negative Activity. Antibiotics, Volume 6(1), pp. 1-11

$\mathrm{Fu}, \mathrm{X} ., \mathrm{Wang}, \mathrm{Z}$., Lu, S., 1996. Mechanisms and Solubility Equations of Gas Dissolving in Water. Science in China, Series B: Chemistry, Volume 39(5), pp. 500-508

Ghatak, M.D., Mahanta, P., 2017. Kinetic Model Development for Biogas Production from Lignocellulosic Biomass. International Journal of Technology, Volume 8(4), pp. 673-680

Gross, E.L., Cravotta III, C.A., 2016. Groundwater Quality for 75 Domestic Wells in Lycoming Country, Pennsylvania, 2014. Scientific Investigation Report 2016-5143, U.S. Department of the Interior and U.S. Geological Survey

Horikawa, M.S., Rossi, F., Gimenes, M.L., Costa, C.M.M., da Silva, M.G.C., 2004. Chemical Absorption of $\mathrm{H}_{2} \mathrm{~S}$ for Biogas Purification. Brazilian Journal of Chemical Engineering, Volume 21, pp. 415-422

Islamiyah, M., Soehartanto, T., Hantoro, R., Abdurrahman, A., 2015. Water Scrubbing for Removal of $\mathrm{CO}_{2}$ (Carbon Dioxide) and $\mathrm{H}_{2} \mathrm{~S}$ (Hydrogen Sulfide) in Biogas from Manure. KnE Energy, Volume 2(2), pp. 126-131

Kapoor, R., Subbarao, P.M.V., Vijay, V.K., Shah, G., Sahota, S., Singh, D., Verma, M., 2017. Factors Affecting Methane Loss from a Water Scrubbing Based Biogas Upgrading System. Applied Energy, Volume 208, pp. 1379-1388

Kusrini, E., Lukita, M., Gozan, M., Susanto, B.H., Widodo, T.W., Nasution, D.A., Wu, S., Rahman, A., Siregar, Y.D.I., 2016. Biogas from Palm Oil Mill Effluent: Characterization and Removal of $\mathrm{CO}_{2}$ using Modified Clinoptilolite Zeolites in a Fixed-Bed Column. International Journal of Technology, Volume 7(4), pp. 625-634

Latif, M.A., Mehta, C.M., Batstone, D.J., 2014. Improved Phosphorus Solubility During Acidic Anaerobic Digestion. In: AWA Biosolids Conference, pp. 1-7, Melbourne, Australia

Lin, E.S., 2004. A Modelling Study of $\mathrm{H}_{2} \mathrm{~S}$ Absorption in Pure Water and in Rainwater. Master's Thesis, Graduate Program, National University of Singapore, Singapore

Macgregor, R.J., Mather, A.E., 1991. Equilibrium Solubility of $\mathrm{H}_{2} \mathrm{~S}$ and $\mathrm{CO}_{2}$ and Their Mixtures in a Mixed Solvent. The Canadian Journal of Chemical Engineering, Volume 69(6), pp. 1357-1366

Maile, O.I., Muzenda, E., Tesfagiorgis, H., 2017. Chemical Absorption of Carbon Dioxide in Biogas Purification. Procedia manufacturing, Volume 7, pp. 639-646

Ofori-Boateng, C., Kwafie, E.M., 2009. Water Scrubbing: A Better Option for Biogas Purification for Effective Storage. World Applied Science Journal, Volume 5, pp. 122-125

Noorain, R., Kindaichi, T., Ozaki, N., Aoi, Y., Ohashi, A., 2019. Biogas Purification Performance of New Water Scrubber Packed With Sponge Carriers. Journal of Cleaner Production, Volume 214, pp. 103-111

Petersson, A.W., 2014. Biogas Upgrading Technologies - Developments and Innovations. IEA Bioenergy, Sweden

Shah, D.R., Nagarsheth, H.J., Pradeep, A., 2016. Purification of Biogas using Chemical Scrubbing and Application of Purified Biogas as Fuel for Automotive Engines. Research Journal of Recent Sciences, Volume 5, pp. 1-7

Recebli, Z., Selimli, S., Ozkaymak, M., Gonc, O., 2015. Biogas Production from Animal Manure. Journal of Engineering Science and Technology, Volume 10(6), pp. 722-729 
Sarono., Suparno, O., Suprihatin, S., Hasanudin, U., 2016. The Performance of Biogas Production from Pome at Different Temperatures. International Journal of Technology, Volume 7(8), pp. 1413-1421

Revsbech, N.P., Garcia-Robledo, E., Sveegaard, S., Andersen, M.H., Gothelf, K.V., Larsen, L.H., 2019. Amperometic Microsensor for Measurement of Gaseous and Dissolved $\mathrm{CO}_{2}$. Sensors and Actuators B: Chemical, Volume 283, pp. 349-354

Songolzadeh, M., Soleimani, M., Takht Ravanchi, M., Songolzadeh, R., 2014. Carbon Dioxide Separation from Flue Gases: A Technological Review Emphasizing Reduction in Greenhouse Gas Emissions. The Scientific World Journal, Volume 2014, pp. 1-34

Tahir, M.S., Shahid, Z., Shahzad, K., Sagir, M., Rehan, M., Nizami, A.S., 2015. Producing Methane Enriched Biogas using Solvent Absorption Method. Chemical Engineering Transactions, Volume 45, pp. 1309-1314

Wahyuono, R.A., Hakim, M.N., Santoso, S.A., 2015. Feasibility Study on the Production of Bioethanol from Tapioca Solid Waste to Meet the National Demand of Biofuel. Energy Procedia, Volume 65, pp. 324-330

Wang, Y., Liu, Y., Wang, Y., 2020. Oxidation Absorption of Hydrogen Sulfide from Gas Stream using Vacuum Ultraviolet/ $\mathrm{H}_{2} \mathrm{O}_{2} /$ Urea Wet Scrubbing System. Process Safety and Environmental Protection, Volume 140, pp. 348-355 